\title{
CYTOMEGALOVIRUS CHRONIC INFECTION AS A RISK FACTOR FOR STROKE: A PROSPECTIVE STUDY
}

\author{
Viktorija Ķēniņa*, Pauls Auce**, Zanda Priede*, Inese Irbe**, Lana Vainšteina**, \\ Elvira Smeltere ${ }^{\star \star *}$, and Andrejs Millers* \\ * Rīga Stradinš University, Dzirciema ielā 16, LV-1007, LATVIA; \\ Pauls Stradinš University Hospital, Pilsonu ielā 13, LV-1002, LATVIA; \\ e-mail: vikakenina@ inbox.Iv \\ ** Pauls Stradiṇš University Hospital, Pilsoṇu ielā 13, LV-1002, LATVIA \\ *** Rīga Stradinš̌ University, Dzirciema ielā 16, LV-1007, LATVIA
}

Communicated by Igors Aksiks

\begin{abstract}
Stroke is the second most common cause of death in the world and a major cause of long-term disability. Chronic infection is an independent risk factor for ischemic stroke and related forms of atherosclerotic vascular disease. The aim of our study was to compare the plasma Cytomegalovirus (CMV) immunoglobulin G antibody level in a patient and control group, and to determine the association of CMV chronic infection with ischemic stroke, and with stroke subtype. The present study does not present a cogent demonstration that cytomegalovirus chronic infection is a risk factor of stroke. Further studies are necessary to clarify the effective prophylactic measures to determine other significant risk factors for stroke.
\end{abstract}

Key words: chronic infection, stroke, cytomegalovirus infection.

\section{INTRODUCTION}

The inflammatory nature of atherosclerosis and certain links between infection and atherothrombosis have been described by many researchers (Ross, 1973; Ross et al., 1976; Ross, 1986; 1993a; 1993b).

Chronic infection could be one of the possible causative factors involved as it causes dysfunction and inflammation of endothelium (Libby et al., 1997). Infection agents and viruses damage and transform the vascular wall, thus directly causing endothelium and smooth muscle cell dysfunction. Indirect influence on both atherosclerosis and atherothrombosis can occur by affecting leukocytes (including macrophages and lymphocytes, commonly found in atheromata) in the following ways: decrease of fibrinolytic activity, stimulation of procoagulant and cytotoxin production, and atherogenic changes in lipid metabolism. Infectious agents are essential for the immune system activation; it has been shown that flu vaccinated individuals less frequently develop acute vascular events, compared to unvaccinated people (Nichol et al., 2003; Smeeth et al., 2004).

Cytomegalovirus (CMV), known as Human Herpesvirus (HHV5), belongs to the beta Herpes virus subfamily (Mocarski et al., 2001) and is found in all geographic regions and socioeconomic groups (Ryan et al., 2004). CMV infects between $50 \%$ and $80 \%$ of the population, and its seroprevalence is age-dependent. CMV may affect any organ. As a latent infection it persists in the organism over long periods, and intermittently can be transmitted to the environment. The virus is associated with the salivary glands. Development of CMV is dependent on many factors: route of infection, genetic features of the host, as well as the immune system status. CMV can be found in all bodily fluids — urine, saliva, tears, sperm, and breast milk (Ho, 1990). Postnatally, infection mainly affects the respiratory and digestive systems. In blood CMV mainly replicates in macrophages (leukocytes and monocytes), or persists in the lymphoid tissues. A CMV infected macrophage induces MCR-1 (monocyte chemotactic protein) expression. Therefore, CMV can be considered as a MCR-1 expression "mediator", the mechanism leading to endothelial damage (Stern et al., 2008). Similar to Chlamydia pneumoniae, chronic CMV infection is also associated with vascular smooth muscle cell proliferation (Epstein et al., 1999 ) and increase of carotid atherosclerosis and intima media thickness (Nieto et al., 1996). Studies focused on CMV identification in atherosclerotic plaques have showed ambiguous results, moreover, virus antibody titres have not always correlated with clinical findings (Chiu et al., 1997; Saetta et al., 2000). CMV diagnostics are based on serologic and molecular methods.

The aim of our study was to compare the plasma Cytomegalovirus IgG antibody level in a stroke patient and control groups and to determine association of homocysteine with ischemic stroke and with stroke subtype. 


\section{MATERIALS AND METHODS}

This study was prospective and all patients $(n=102)$ included in this study were hospitalised in Pauls Stradiñ̌ Clinical University Hospital in the Clinic of Neurology with the diagnosis of acute ischemic stroke (61 males, $41 \mathrm{fe}-$ males; mean age $65.8 \pm 10.9$ years; age range 42 to 89 years). The control group included 48 people ( 26 males, 22 females; mean age: $64.3 \pm 11.8$ years; age range 42 to 82 years). Patients were divided into three groups according to TOAST criteria: patients with atherotrombotic stroke subtype $(n=36)$, cardioembolic stroke subtype $(n=47)$ and with undetermined aetiology subtype $(\mathrm{n}=19)$. General characteristics of the 102 cases in subgroups are presented in Tables 1 and 2. The average age of patients in subgroups significantly differed $(\mathrm{F}=4.631 ; P<0.05)$, which can be explained by different pathogenesis and aetiology mechanisms in the stroke subgroups.

Table 1

AVERAGE AGE IN PATIENT GROUPS

\begin{tabular}{l|c|c|r|cc}
\hline \multirow{1}{c|}{$\begin{array}{c}\text { Patient } \\
\text { subgroup }\end{array}$} & $\mathrm{N}$ & $\mathrm{M}$ & $\mathrm{SD}$ & \multicolumn{2}{c}{$\begin{array}{c}95 \% \text { confidence } \\
\text { interval for mean }\end{array}$} \\
\cline { 5 - 6 } & & & & $\begin{array}{c}\text { lower } \\
\text { bound }\end{array}$ & $\begin{array}{c}\text { upper } \\
\text { bound }\end{array}$ \\
\hline Atherotrombotic & 36 & 63.2 & 11.3 & 59.4 & 67.02 \\
Cardioembolic & 47 & 69.9 & 8.8 & 67.4 & 72.51 \\
Undetermined & 19 & 60.7 & 11.9 & 54.9 & 66.44
\end{tabular}

Table 2

PATIENT DIVISION ACCORDING TO GENDER IN EACH SUBGROUP

\begin{tabular}{l|c|c}
\hline \multirow{2}{*}{ Stroke subgroup } & \multicolumn{2}{|c}{ Gender } \\
\cline { 2 - 3 } & male & female \\
\hline Atherotrombotic & $28(77.8 \%)$ & $8(22.2 \%)$ \\
Cardioembolic & $21(44.6 \%)$ & $26(45.4 \%)$ \\
Undetermined & $12(63.2 \%)$ & $7(36.8 \%)$
\end{tabular}

The severity of neurological status of patients was clinically evaluated using the Rankin scale. Special inquiry forms were completed for each of patients with the following information: stroke localisation (ACM, ACA or VB territory), and stroke risk factors (hypertension, diabetes, cigarettesmoking, blood lipids and others).

Quantitative/qualitative determination of $\operatorname{IgG}$ antibodies to Cytomegalovirus in plasma and sera (ADALTIS EIAgen Cytomegalovirus IgG Kit) in plasma was conducted by ELISA. The test had in vitro diagnostic use only. Microplates are coated with native Cytomegalovirus antigen, highly purified by sucrose gradient centrifugation and inactivated. The solid phase was first treated with the diluted sample and immunoglobulin $\mathrm{G}$ ( $\operatorname{IgG}$ ) to Cytomegalovirus were captured, if present, by the antigens. After washing out all of the components of the sample, in the $2^{\text {nd }}$ incubation, bound anti Cytomegalovirus Ig $\mathrm{G}$ were detected by the addition of polyclonal specific and $\mathrm{hIgG}$ antibodies, labelled with peroxidase (HRP). The enzyme captured on the solid phase, acting on the substrate/chromogen mixture, generates an optical signal that is proportional to the amount of anti CMV IgG antibodies present in the sample. A Calibration Curve, calibrated as the $1^{\text {st }} \mathrm{WHO}$ international standard was used for quantitative determination of the $\operatorname{IgG}$ antibody in the patient. Samples with a concentration lower than 0.5 $\mathrm{IU} / \mathrm{ml}$ are considered negative for anti Cytomegalovirus IgG antibody. Samples with a concentration higher than 0.5 $\mathrm{IU} / \mathrm{ml}$ were considered positive for anti-CMV IgG antibody. Persons with blood samples whose anti-CMV IgG antibody concentration was expected to be higher than $8 \mathrm{IU} / \mathrm{ml}$ in this study were classified as patients who had massive contact with virus.

SPSS 16 software was used for statistical data processing. To test hypotheses in line with the set tasks and type of data the parametric and non-parametric statistical methods were used.

\section{RESULTS}

CMV IgG seropositivity was not associated with a particular case group. The prevalence of Ig G higher than 0.5 $\mathrm{IU} / \mathrm{ml}$ did not differ between patient and control groups $\left(\chi^{2}=0.02 ; P>0.05\right)$ (Table 3). Subgroup analyses show similar negative results (Table 4 ).

The mean CMV IgG antibody level was not significantly higher in the patient group $(\mathrm{t}=1.274 ; P>0.05)$ (Table 5). There was no significant difference between mean level of CMV antibody in different stroke subtypes ( $\mathrm{F}=3.27 ; P<$ 0.05) (Table 6).

The patient and control groups were divided into two subgroups - with $\mathrm{IgG}$ to $\mathrm{CMV}$ level from $0.5 \mathrm{IU} / \mathrm{ml}$ to 8

Table 3

NUMBERS OF PATIENTS WITH CMV IgG HIGHER THAN 0.5 IU/ML IN PATIENT AND CONTROL GROUPS*

\begin{tabular}{lcc|c}
\hline & $\begin{array}{c}\text { Cases group } \\
(\mathrm{n}=102)\end{array}$ & $\begin{array}{c}\text { Control group } \\
(\mathrm{n}=48)\end{array}$ & $\chi^{2}$ \\
\hline $\begin{array}{l}\text { Patients with CMV IgG } \\
\text { higher than } 0.5 \mathrm{IU} / \mathrm{ml}(\mathrm{n})\end{array}$ & 95 & 45 & 0.02 \\
\hline
\end{tabular}

IgG, immunoglobulin $\mathrm{G} ; * P>0.05$; CMV, Cytomegalovirus

Table 4

THE PROPORTION (\%) OF PATIENTS WITH CMV IgG HIGHER THAN 0.5 IU/MIN IN GROUPS WITH DIFFERENT STROKE SUBTYPES AND WITH CONTROL GROUP*

\begin{tabular}{l|c|c|c}
\hline & $\begin{array}{c}\text { Stroke subtype } \\
\text { CMV IgG higher } \\
\text { than 0.5 IU/ml } \\
(\%)\end{array}$ & $\begin{array}{c}\text { Control group } \\
\text { CMV IgG higher } \\
\text { than } 0.5 \mathrm{IU} / \mathrm{ml} \\
(\%)\end{array}$ & $\chi^{2}$ \\
\hline Atherotrombotic & 97 & 93 & 1.68 \\
Cardioembolic & 92 & 93 & 0.07 \\
Underterminated & 86 & 93 & 2.61
\end{tabular}

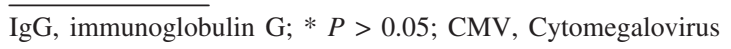


MEAN CMV IgG ANTIBODY LEVEL IN PATIENT AND CONTROL GROUPS*

\begin{tabular}{l|c|c}
\hline & $\begin{array}{c}\text { Patient group } \\
(\mathrm{n}=102)\end{array}$ & $\begin{array}{c}\text { Control group } \\
(\mathrm{n}=48)\end{array}$ \\
\hline $\begin{array}{l}\text { Mean CMV IgG antibody level } \\
(\mathrm{IU} / \mathrm{ml})\end{array}$ & $6.43 \pm 2.6$ & $5.83 \pm 2.7$
\end{tabular}

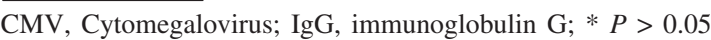

Table 6

MEAN CMV IgG ANTIBODY LEVEL (IU/ML) IN DIFFERENT STROKE SUBTYPES

\begin{tabular}{l|c|c|c|c|c}
\hline & N & M & SD & \multicolumn{2}{|c}{$\begin{array}{c}\text { 95\% confidence } \\
\text { interval for mean }\end{array}$} \\
\cline { 5 - 7 } & & & & $\begin{array}{c}\text { lower } \\
\text { bound }\end{array}$ & $\begin{array}{c}\text { upper } \\
\text { bound }\end{array}$ \\
\hline Atherotrombotic stroke & 36 & 6.392 & 2.4168 & 5.416 & 7.368 \\
Underterminated stroke & 19 & 5.019 & 3.4431 & 3.359 & 6.678 \\
Cardioembolic stroke & 47 & 7.022 & 2.0625 & 6.417 & 7.628 \\
Control group & 48 & 5.833 & 2.7181 & 5.044 & 6.623 \\
Total & 150 & 6.226 & 2.6389 & 5.785 & 6.667
\end{tabular}

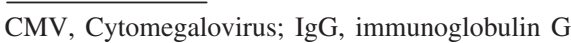

$\mathrm{IU} / \mathrm{ml}$ and above $8 \mathrm{IU} / \mathrm{ml}$ (Table 7). The prevalence of seropositivity to $\mathrm{IgG}(>8 \mathrm{IU} / \mathrm{ml})$ antibodies was significantly higher in cardioembolic stroke cases $(75 \%)$ than in controls $(52 \%)(\mathrm{x}=5.11 ; P<0.05)$. These results suggest that associations between high concentration of anti CMV $\mathrm{IgG}$ and atherosclerosis is mostly found in cardiovascular patients.

We found a correlation between CMV IgG antibody level and leucocitosis $(\mathrm{r}=0.282 ; P<0.05)$, coronary heart disease $(\mathrm{r}=0.239 ; P<0.05)$, and thickness of intima-media complex $(\mathrm{r}=0,221 ; P<0.05)$, which might suggest $\mathrm{CMV}$ seropositivity as a stimulator of chronic inflammation and an independent predictor of atherosclerosis.

\section{DISCUSSION}

Our study does not provide an unambiguous answer on the role of chronic infection in stroke etiology. Several problems should be solved in order to confirm the infection theory. Chronic infection is widespread in the population, and therefore, can not be considered as a specific risk factor. In our study, CMV IgG seropositivity was detected in $93 \%$ of the patient group and in $94 \%$ of the control group cases. Cytomegalovirus chronic infection is an associate with proliferation of vascular smooth-muscle cells (Epstein et al., 2004) and increase thickness of intima-media complex (Nieto et al., 1996). In our study, we also found a correlation between CMV IgG antibody level and thickness of intima-media complex $(\mathrm{r}=0.221 ; P<0.05)$. We can not also exclude the importance of cytomegalovirus chronic infection combination with other risk factors, such as coronary heart disease (Amarenco et al., 1994) and white blood cell count (Grau et al., 2001). This study shows an association between CMV IgG antibody level and leucocitosis ( $\mathrm{r}=$ $0.282 ; P<0.05)$ and coronary heart disease $(\mathrm{r}=0.239 ; P<$ $0.05)$.

It still remains unclear whether chronic infection induces the onset of atherosclerosis, or merely contributes to the progression of the latter. In the search for clinical evidence for the chronic infection theory, more verified associations between microorganisms and atherosclerosis have been mostly found in cardiovascular patients, where diversity of risk factors have been excluded. This can be difficult to achieve in stroke patients due to stroke heterogeneity.

Another important problem to solve is the methodology of detection: the optimal method for detecting of the infectious agents has not been accepted yet. The role played by molecular methods in a routine diagnostic virus laboratory is still small compared to conventional methods. One of the newer molecular techniques is the polymerase chain reaction (PCR). PCR has many problems, mainly contamination, since only a minute amount of contamination is needed to give a false positive result. In addition, because PCR is so sensitive compared to other techniques, a positive PCR result is often very difficult to interpret as it does not necessarily indicate the presence of disease. This problem is particularly large in the case of latent viruses such as CMV, since latent CMV genomes may be amplified from the blood of healthy individuals. Serology forms the mainstay of viral diagnosis, as it shows primary humoral immune response to antigen. The ELISA method is relatively cheap, sufficiently sensitive and more often is used as a routine method in clinical practice.

The definition of chronic infection in perspective probably can be recommended as a routine analysis, especially for stroke patients with dyslipidemia, coronary heart disease,

Table 7

COMPARISON BETWEEN STROKE SUBTYPE GROUPS, WITH CMV IGG LEVEL BELOW/ABOVE 8 IU/ML, AND CONTROL GROUP

\begin{tabular}{l|c|c|c|c}
\hline Subgroup & $\begin{array}{c}\text { Atherotrombotic } \\
\text { stroke(n=36) }\end{array}$ & $\begin{array}{c}\chi^{2} ; \\
P\end{array}$ & $\begin{array}{c}\text { Cardioembolic } \\
\text { stroke (n=47) }\end{array}$ & $\begin{array}{c}\chi^{2} ; \\
P\end{array}$ \\
\hline $\begin{array}{l}\text { Patient group/ control group with IgG } \\
\text { CMV < 8 IU/ml }\end{array}$ & $14 / 23$ & $0.96 ;$ & $12 / 23$ & $5.11 ;$ \\
Patient group/ control group with IgG & $22 / 25$ & $>0.05$ & $35 / 25$ & $0.68 ;$ \\
\hline
\end{tabular}

$\mathrm{CMV}>8 \mathrm{IU} / \mathrm{ml}$

CMV, Cytomegalovirus; IgG, immunoglobulin G 
and stenotic changes in carotid vessels. It remains necessary to continue studies to clarify the role of chronic infection in the Latvian population. CMV detection in native tissue may be the next step to the investigation of tropism of infection.

\section{ACKNOWLEDGMENTS}

This research was supported by European Social Fund.

\section{REFERENCES}

Amarenco, P., Cohen, A., Tzourio, C. Bertrand, B., Hommel, M., Besson, G., Chauvel, C., Touboul, P.J., Bousser, M.G. (1994). Atherosclerosis disease of the aortic arch and the risk of ischemic stroke. New Engl. J. Med., 331, 1474-1479.

Chiu, B., Viira, E., Tucker, W., Fong, I.W. (1997). Chlamydia pneumoniae, cytomegalovirus, and herpes simplex virus and atherosclerosis of the carotid artery. Circulation, 96, 2144-2148.

Grau, A.J., Weimar, C., Buggle, F., Heinrich, A., Goertler, M., Neumaier, S., Glahn, J., Brandt, T., Hacke, W., Diener, H.-C. (2001). Risk factors, outcome, and treatment in subtypes of ischemic stroke: The German stroke data bank. Stroke, 32, 2559-2566.

Epstein, S.E., Zhou, Y.F., Zhu, J. (1999). Infection and atherosclerosis: Emerging mechanistic paradigms. Circulation, 100, 20-28.

Ho, M. (1990). Epidemiology of cytomegalovirus infections. Rev. Infect. Dis., 12(7), 701-710.

Libby, P., Egan, D., Skarlatos, S. (1997). Roles of infectious agent in atherosclerosis and restenosis: An assessment of the evidence and need for future research. Circulation, 96, 4095-4103

Mocarski, E.S., Courcelle, C.T. (2001). Cytomegaloviruses and their replication. In: Field's Virology (pp. 2629-2674). Knipe, D.M., Howley, P.M.,
Griffin, D.E., Martin, M.A., Lamb, R.A., Roizman, B., Straus, S.E. (eds) Philadephia, PA: Lippincott-Raven Publishers.

Nichol, K.L., Nordin, J., Mullooly, J., Lask, R., Fillbrandt, K., Iwane, M. (2003). Influenza vaccination and reduction in hospitalizations for cardiac disease and stroke among the elderly. New Engl. J. Med., 348(14), 1322-1332.

Nieto, F.J., Adam, E., Sorlie, P., Farzadegan, H., Melnick, J.L., Comstock, G.W., Szklo, M. (1996). Cohort study of cytomegalovirus infection as a risk factor for carotid intimal-medial thickening, a measure of subclinical atherosclerosis. Circulation, 94, 922-927.

Ross, R., Glomset, J.A. (1973). Atherosclerosis and the arterial smooth muscle cell: Proliferation of smooth muscle is a key event in the genesis if the lesions of atherosclerosis. Sience, 180, 1332-1339.

Ross, R., Glomset, J.A. (1976). The pathogenesis of atherosclerosis. New Engl. J. Med., 295, 369-377, 420.

Ross, R. (1986). The pathogenesis of atherosclerosis: An update. New Engl. J. Med, 314, 488-500.

Ross, R. (1993). The pathogenesis of atherosclerosis: A perspective for the 1990s. Nature, 362, 801-809.

Ross, R. (1993). Atherosclerosis: A defense mechanism gone awry. Amer. J. Pathol., 143, 987-1002.

Ryan, K.J., Ray, C.G. (2004). Sherris Medical Microbiology. 4th ed. New York: McGraw Hill, 556; pp. 566-569.

Saetta, A., Fanourakis, G., Agapitos, E., Davaris, P.S. (2000). Atherosclerosis of the carotid artery: Absence of evidence for CMV involvement in atheroma formation. Cardiovasc. Pathol., 9, 181-183.

Smeeth, L., Thomas, S.L., Hall, A.J., Hubbard, R., Farrington, P., Vallance, P. (2004). Risk of myocardial infarction and stroke after acute infection or vaccination. New Engl. J. Med., 351(25), 2611-2618.

Stern, J., Slobedman, B. (2008). Human Cytomegalovirus latent infection of myeloid cells directs monocyte migration by up-regulating monocyte chemotactic protein-1. J. Immunol., 180(10), 6577-6585.

Received 5 October 2009

\section{CITOMEGALOVĪRUSS KĀ CEREBRĀLA INFARKTA RISKA FAKTORS: PROSPEKTĪVS PĒTĪJUMS}

Citomegalovīruss (CMV) ir zināms arī kā cilvēka herpesvīruss 5 (HHV5), tas pieder pie beta herpesvīrusu dzimtas un ir sastopams visos ğeogrāfiskajos reǵionos un sociālekonomiskajās grupās. Ar CMV inficēti 50-80\% populācijas un tās seroprevalence tieši korelē ar vecumu. Nonākot asinīs, CMV reproducējās leikocītos un monocitāto makrofāgu sistēmas šūnās vai persistē limfoīdos audos. Makrofāgs, kas ir inficēts ar vīrusu, sāk stimulēt MCR-1 ekspresiju, līdz ar to CMV var nosaukt par starpnieku MCR-1 ekspresijas procesā - tas ir mehānisms, kas veicina endotēlija bojājumu. Hroniska CMV infekcija varētu būt viens no iespējamajiem iesaistītajiem faktoriem, kas izraisa endotēlija disfunkciju un iekaisumu, stimulējot aterosklerozi. Mūsu pētījuma mērkis bija izpētīt citomegalovīrusa hronisko infekciju kā cerebrāla infarkta riska faktoru, tā saistību ar insulta apakštipu un citiem riska faktoriem. Pētījums veikts Paula Stradina Klīniskajā universitātes slimnīcā Neiroloǵijas nodaḷā, un tajā piedalījās 150 cilvēki. Pētījumā pamata grupā bija iesaistīti 102 pacientí, no tiem 61 vīrietis un 41 sieviete vecumā no 42 līdz 89 gadiem, vidējais vecums 65,8 \pm 10,9 gadi. Kontroles grupā bija 48 cilvēki, no tiem 26 vīrieši un 22 sievietes vecumā no 42 līdz 82 gadiem, vidējais vecums $64,3 \pm 11,8$ gadi. Pacientu grupai un kontroles grupai bija noteikts imūnglobulīna G (Ig G) CMV līmenis asinīs. Pozitīvas IgG antivielas pret CMV tika atrastas 95 pacientiem no $102(92,2 \%)$ slimnieku grupā un 45 no 48 kontrolgrupas dalībniekiem. Rezultāti starp grupām statistiski ticami neatškīīās $\left(\chi^{2}=0.02 ; P>0,05\right)$. Vidējais CMV antivielu līmenis asins serumā pacientu grupā bija nedaudz augstāks nekā kontrolgrupai, bet rezultāti statistiski ticami neatšḳīrās $(\mathrm{t}=1,274$; $P>0,05)$. Analizējot pozitīvas antivielas pret CMV statistiski ticama korelācija bija atrasta ar iekaisuma radītāju - leikocitozi $(\mathrm{r}=0,282$; $P<0,01)$, pozitīvām antivielām pret CMV un KSS ( $\mathrm{r}=0,239 ; P<0,05)$, pozitīiām antivielām pret CMV un intīma-media kompleksa biezumu $(\mathrm{r}=0,221 ; P<0,05)$. Korelācija ar citiem insulta riska faktoriem netika atrasta. 